\title{
CURRENT NORTHERN EURASIA FOREST CONDITION: METHODS OF ANALYSIS AND RESTORATION OF NATURAL BIOTA IN PROTECTED AREAS. \\ LITERATURE REVIEW AND RECOMMENDATIONS FOR REQUIRED RESEARCH IN PROTECTED AREAS
}

\section{O. V. Smirnova}

Center for Problems of Ecology and Productivity of Forests, Russian Academy of Sciences, 84/32 Profsoyuznaya Street, Moscow, 117997, Russia

E-mail: ovsinfo@gmail.com

\section{A. P. Geraskina}

Center for Problems of Ecology and Productivity of Forests, Russian Academy of Sciences, 84/32 Profsoyuznaya Street, Moscow, 117997, Russia;

Moscow Pedagogical State University, 6 Kibalchicha st., bldg. 5, Moscow, 129164, Russia

E-mail: angersgma@gmail.com

\section{СОВРЕМЕННОЕ СОСТОЯНИЕ ЛЕСОВ СЕВЕРНОЙ ЕВРАЗИИ: МЕТОАЫ АНАЛИЗА И ВОССТАНОВЛЕНИЯ ПРИРОДНОЙ БИОТЫ В ОСОБО ОХРАНЯЕМЫХ ПРИРОДНЫХ ТЕРРИТОРИЯХ. ОБЗОР ЛИТЕРАТУРЫ И РЕКОМЕНААЦИИ НЕОБХОДИМЫХ ИССЛЕДОВАНИЙ В ОСОБО ОХРАНЯЕМЫХ ПРИРОДНЫХ ТЕРРИТОРИЯХ}

\section{О. В. Смирнова}

Центр по проблемам экологии и продуктивности лесов РАН, Россия, 117485, Москва, ул. Профсоюзная, 84/32 E-mail: ovsinfo@gmail.com

\section{А. П. Гераськина}

Центр по проблемам экологии и продуктивности лесов РАН, Россия, 117485, Москва, ул. Профсоюзная, 84/32; Московский педагогический государственный университет, Россия, 129164, Москва, ул. Кибальчича, 6, корп. 5 E-mail: angersgma@gmail.com

Abstract. The reconstruction of the verbal pre-anthropogenic Northern Eurasia forest cover has been proposed on the basis of paleontology and historical ecology data analysis. It was used as a basis for evaluating the ability of the reserves in the studied area to act as reference objects capable of performing the ecosystem living soil cover functions. The analysis indicated immense anthropogenic transformation of the Biota in this territory and the requirement for urgent measures to restore the full-fledged Biota of the reserves at the state and global levels. A list of necessary activities for the initial phase of Biota recovery in the modern protected areas has been proposed.

Keywords: reserves, paleoreconstruction, reintroduction, key species, phytophagous mammoth complex giants, Würm, "prehistoric pasture paradox", "uncompensated Würm extinction paradox".

For citation: Smirnova O.V., Geraskina A.P. Current northern Eurasia forest condition: methods of analysis and restoration of natural biota in protected areas. Literature review and recommendations for required research in protected areas. Russian Journal of Ecosystem Ecology. 2019;4(1). Available from: https://doi.org/10.21685/25000578-2019-1-1

Аннотация. На основе анализа данных палеонтологии и исторической экологии предложена вербальная реконструкция доантропогенного лесного покрова Северной Евразии. На ее основе проведена оценка возможности заповедников анализируемой территории выступать как эталонные объекты, способные реализовать экосистемные функции живого покрова. Анализ показал огромную степень антропогенной преобразованности биоты этой территории и необходимость принятия срочных мер восстановления полноценной биоты заповедников на государственном и общечеловеческом уровнях. Предложен перечень необходимых действий для начального этапа восстановления биоты современных особо охраняемых природных территорий. 
Ключевые слова: заповедники, палеореконструкции, реинтродукция, ключевые виды, гиганты-фитофаги мамонтового комплекса, вюрм, «парадокс доисторических пастбищ», «парадокс некомпенсированных вюрмских вымираний».

The increasing awareness of HUMANITY dependence on the BIOSPHERE state forces us to identify the problems to be solved BY THE ENTIRE WORLD with the suggestion of the possible solutions. The essence of these problems is as follows: the modern living cover of Earth cannot support the conditions necessary for the sustainable existence of humankind, namely: optimal climate, hydrological and temperature conditions, soil fertility and biological diversity, since most of its territory is devoid of natural cover [1-5] for which it acquired a completely fair name: "Scalped Earth" [6].

The created reserve territories (protected areas) have been considered by their organizers as the standards of Nature not yet transformed by human beings $[7,8]$. The study of the laws of their existence has been assumed to serve as a basis for the solution of the environmental management problems focused on the maintenance of the ecosystem functions of Earth Biota for the humanity survival: biodiversity, high productivity and climate optimization.

Approximately 100 years have passed since the creation of the first protected areas in Russia. During this time, huge paleo data have been accumulated and paleo reconstructions have been conducted which allowed analyzing the history of the living cover on Earth from the beginning of the Anthropogenic era: a period in Earth development during which man became the main medium transforming force through climate change, hydrological regime, biological diversity, biological productivity and other properties of Earth natural cover.

A new science - historical ecology - has arisen on the basis of a conjugate analysis of paleo data and archival documents. The anthropobiotic concept has been created in the process of its development being a well-argued idea of the decisive role of humans in the sequential destruction of the structural and functional organization of Earth Biota due to massive destructions of key species that determined the possibility of the full implementation of the Biota ecosystem functions in the preanthropogenic period [9-11].

Currently, the tremendous advances of paleontology and historical ecology make it possible to create the model reconstructions of the prehistoric composition and structure of Biota from different territories and evaluate their capabilities in the process of optimization of the ecosystem functions of Earth Biota [12-28].
In this regard, the territory of the reserves and other protected areas considered as the standards of nature attracts most attention.

It is believed that the detailed studies of these territories and identification of the ways of existence and development of the remaining "fragments of nature" will allow us to optimize the ways of nature management and thereby prolong the survival time of humanity on Earth [24, 26-28, 29].

By now, the synthesis of paleontology and historical ecology data enables the reconstruction of a significant part of the BIOTA in protected areas.

It becomes obvious that the territories of most protected areas of the forest belt in Northern Eurasia experienced a powerful anthropogenic impact at the early stages of human development with the increase of such reconstructions; therefore they need not only to preserve the surviving living area, but also to restore its full composition and structure.

The studies demonstrated that the size of the territories of most protected areas is so small that they are not able to maintain steady flows of generations in the populations of many species of animals, plants or representatives of other kingdoms that have still remained. Moreover, they cannot accommodate the species that once lived there, but are now preserved only in separate refugia [19-24, 27-35].

Therefore, the restoration of the optimal for the humanity state BIOSPHERE is possibly based on the coordination of fundamentally new methods of environmental management and conservation of NATURE developed according to the laws of ecology.

The first step in this direction is to evaluate the degree of anthropogenic transformation of the protected areas based on paleo reconstructions and analysis of the history of environmental management in their territories [20, 24, 28, 30].

To our regret, it should be noted that the use of the world advances in natural sciences for evaluating the current state of our country's reserves is almost impossible. This is due to poor financing, insufficient staffing in different areas, lack of equipment, inability to enhance knowledge when studying the world advances and perform experiments on the reintroduction of species exterminated in the analyzed territories as a result of previous environmental management. It is also related to the rapid decline in the educational level in the field of natural sciences at all levels: from schools to universities. 
It should be noted that the problem of evaluating the Biota inferiority in protected areas has repeatedly arisen in the public mind and one of the results was the experiments on reintroduction of certain key animal species: bison, beaver, horse, marmot, etc. The reintroduction organizers suggested that the addition of species into the Biota of protected areas according to the paleo data and historical ecology information would lead to an increase in their diversity and the resilience of ecosystems as a whole to anthropogenically caused climate changes, biological diversity, productivity and other adverse effects of humanity on NATURE.

Nevertheless, the experiments revealed the imperfection of reintroductions for the following reasons: size of protected areas, diversity of their landscapes, hydrological features and condition of the soil cover degraded as a result of anthropogenic influences $[19,20,24,25,27,28]$ that do not meet the conditions required for the sustainable existence of the populations of key species of land and soil animals, plants and representatives of other kingdoms.

According to the modern studies, the territory of protected areas required for the sustainable existence of the populations of key animal species, even as small as beaver, should be equal to or greater than the area of the small river basin [36].

The size of the territories required for the maintenance of stable flows of generations of larger animals, such as bison, horse, moose, bear, deer, etc., which populations are currently being restored in some reserves, should be much larger.

The Serengeti National Park can be considered as a standard for evaluating the size of the areas required for the existence of a complete set of animals of Northern Eurasia that have survived to the present: large phytophages and predators. Currently, there is a complete set of key animal species similar to such species of Northern Eurasia both preserved to the present time and existing to the end of the Pleistocene - the beginning and middle of the Holocene. The park area is $14,763 \mathrm{~km}^{2}$.

The reintroduction experiment results demonstrate the requirement for a preliminary analysis of all paleo data and information on the history of environmental management accumulated so far in the already established and created reserves [21, 24, $27,28]$ which allows reconstructing the composition and structure of the Biota of the analyzed territory prior to the protected area creation at the present level of knowledge and also evaluating the size of the areas that are currently required to maintain stable flows of generations in the populations of all the species living there.
Realization of the fact that the territory of any reserves was subject to the anthropogenic factors determines the requirement to evaluate the possibilities and methods of the restoration of the natural (pre-anthropogenic) diversity of the Biota in the analyzed territory. The generalization of paleo data and information on the history of environmental management accumulated to date enables a new reconstruction and improvement of the existing reconstruction of the pre-anthropogenic vegetation and animal world of the protected areas of the modern forests in Northern Eurasia. According to paleo reconstructions, field experiments and model experiments conducted by biologists, the living cover of the modern forest belt of Northern Eurasia from the late Pliocene to the early Holocene was represented by forest-meadow and forest-meadowmarsh-river complexes regulated by the key species of giant phytophagous mammoth complex and by groups of conjugate animal species and representatives of other kingdoms $[20,23,24,27,30$, 31, 38-40].

The inconsistency of the modern ideas on Northern Eurasia Würm nature formed as a result of the accumulation of a huge amount of paleo data along with the ideas of geologists who are not familiar with this information was more thoroughly described in classical literature as the "prehistoric pasture paradox" and "uncompensated Würm extinction paradox" [14-16, 24, 26].

Prehistoric pasture paradox essence: 1) according to the ideas of the geologists that exist up to the present, the Würm is a stage of the Ice Age less favorable for the Biota survival [37-39]; 2) according to the enormous material obtained by paleontologists to date, the Würm is a stage of the Ice Age which is most favorable for human exploration of the Northern Eurasia territory [12-16, 19$24,26,33-35]$ which is evidenced by the abundance of bone remnants of large phytophages of the mammoth complex as well as the pollen, spores and other plant residues that make up the feed for these animals.

The remains of buildings, lesions, clothing and jewelry made of wood, bones and skins of animals of various species; arrows and spears made of wood and tusks of mammoths, and other weapons for killing animals at the sites of ancient man, dating from the Würm also indicate that $[21,23,24$, $26,27]$. It also means that the Würm, the analyzed stage of Earth Biota development, was characterized by an enormous amount and significant total biomass of the large phytophagous animals and predators. All the plant species that have survived to the present and many extinct plant species simultaneously existed in this territory as the food base of the giant phytophagous mammoth complex and 
all related species of the land and soil component of the Biota of the analyzed territory.

\section{Uncompensated Würm extinction paradox essence}

Extinction of some groups of species was accompanied by the appearance of other more evolutionarily advanced groups of species during a long evolutionary development. This did not happen in the Würm where the new species did not replace the extinct mammoth fauna. At the same time, the reasons for their disappearance are documented by the gnawed bones, scraps of clothing made of their skins, dilapidated huts with frames made of mammoth tusks and floors covered with the skins of cave lions [19, 22, 27, 30-35]. The mass destruction of phytophagous giants is reflected in the paleontological literature entitled as "noncompensated Würm extinctions". This was the name of the process for which the paleozoologists could not find the natural causes of changes in the composition and structure of the Würm Biota in Northern Eurasia.

The comparison of the concepts called the "prehistoric pasture paradox" and "uncompensated Würm extinction paradox" makes it possible to conclude the inconsistency of the "great glaciation" concept which, upon careful examination, looks paradoxical that has been repeatedly proven by the works of M. V. Lomonosov, I. G. Pidoplichko, V. G. Chuvardinsky, V. N. Kalyakin, R. B. Krapivner and their followers [40-46]. At the same time, this comparison demonstrates the degree of the pre-anthropogenic Biota effect significance on Earth climate. However, the inertia of our thinking impedes the development of the ideas on the huge medium transforming role of the Biota, which supported the existence of life on Earth during both favorable and unfavorable periods of planet existence.

Therefore, the result of modern paleo data allows us to conclude that the Würm is the time of the beginning of huge changes in the existence of the Biota in Northern Eurasia when man became the only species determining its composition, structure and ability for implementing basic ecosystem functions that determines its absolute responsibility for the survival of Earth Biota.

Comparison of the reconstructions of the Biota in Northern Eurasia in the Würm created by paleontologists with the statement of the geological glacialists about this time as the most unfavorable stage of the glacial period for life on Earth raises serious doubts on the reality of the geologists' ideas about the ice age as a whole and on the legibility of the Würm period climate reconstruction. The unfoundedness of the ideas on the features of Earth Biota in the so-called "Ice Age" is the result of the incredible disunity of researchers and confidence in the possibility of understanding individual manifestations of the Life of Earth without constant comparison with general processes at the level of knowledge reached by humanity. This is perfectly demonstrated in the article that analyses the studies of V. G. Chuvardinsky on the Ice Age problem [40], which contains information on the age of mammoth bones (main food of humans in the Würm period) found on the Scandinavian shield covered with $5 \mathrm{~km}$ layer of ice at the time, according to geologists.

The reasons for the misunderstandings that determined the enormous discrepancy between the results of the study in the related fields of natural sciences are due to the narrow specialization of researchers, their immersion in the solution of specific problems without perceiving the need for mutual consistency in understanding the conditions of existence of Earth Biota as a whole.

At present, the most powerful mediumtransformation activity of terrestrial Biota in Northern Eurasia in the late Pliocene - Pleistocene finds confirmations in numerous paleo data, model and field experiments for evaluating the effect of the vital activity of the mammoth complex giant phytophages on the ecosystem functions of Earth Biota during the "Ice Age" [47-49].

The synthesis of the results of paleo data and modern experiments on the restoration of populations of phytophagous giants of the mammoth complex convinces the enormous productivity and considerable biological diversity of prehistoric pastures so that it simultaneously confirms the ideas on the decisive role of Earth Biota in climate optimization, which are increasingly and persistently expressed in the literature.

Comprehension of the current information from the paleontology, historical ecology and population biology data on the composition, structure and methods of interaction of animal species, plants and representatives of other kingdoms enables the reconstructions and analyses of changes in Earth Biota in the development process of the appropriating economy and, then, the producing economy. However, the disunity of representatives of the different areas of biology and other natural sciences does not allow for summarizing data to answer the question concerning the role of the effect of the destruction of the giant phytophages of the mammoth complex on the subsequent change in the appropriating economy that produced and intensified the destruction of the system-forming bonds of Earth 
Biota on the climate control functions of Earth Biota.

The lack of clear ideas about the backbone connections of the land and soil components of Earth Biota is one of the weak points in the solution of the problem of restoration of the Biota natural state on Scalped Earth.

Paleohistory of the Soil Block of Earth Biota is less investigated since major part of the organisms that are large in their biomass is distinguished by poor preservation. They are not subject to fossilization and are poorly detected in paleo materials due to the absence of hard tissues.

In this regard, the reconstruction of the soil biota only on the basis of paleo data is very difficult. The indirect evidence of the rich soil population in the past is: age data (3-9,5 thousand years) of powerful dark-colored relic humus horizons (up to $120 \mathrm{~cm}$ ) on the territory of modern boreal forests and the presence of mull like humus which formation is difficult to imagine without the earthworms [50]. So far and in many respects the relationship in the soil between plant roots, fungi, bacteria, algae, protozoans, soil invertebrates and vertebrates remains a "black box" for the researchers. The current level of the paleoecology and historical ecology development does not allow for offering a fundamentally new system of relationships.

The new molecular genetic methods [51] can now be used to look into the "black box". They allow for the age evaluation, reconstruction of potential distribution and phylogenetic relationships of soil inhabitants. The study of the phylogeography of modern key species of soil-formers of earthworms and the application of molecular methods demonstrate that, for instance, the evolutionary discrepancy between the different lines of the Eisenia nordenskioldi nordenskioldi subspecies living in most of the territory of Russia ranges from 125 thousand to 1 million years [52], i.e., it is possible that the earthworms are an even more ancient group than was considered based on paleo data [53].

Since the soil as a "landscape mirror" [54] reflects the past and current processes occurring in the aboveground parts of the ecosystems, the transformations associated with a fundamental change in biotic factors (forest cover, abundance and diversity of large mammals), as well as a huge diversity of the Biota species certainly affect the soil population and soil structure overall. In the prehistoric ecosystems, the large phytophages of the mammoth complex introduced a significant mass of excrement into the soil, the mineral and organic matter of which was included in the circulation with the use of the coprophagous invertebrates.
However, the corpses of animals were consumed by soil detritophages, as a result, complex organic substances decomposed to simple ones and became available for different groups of soil inhabitants. The soil fertility was formed this way. The plant litter constitutes the main share (up to $90 \%$ ) of the organic material entering the soil [55] in modern forests. Besides, the soil biota habitat mosaic in modern forests is mainly determined only by the features of the relief and vegetation cover.

Comparison of the structural and functional organization of the land and soil spaces in forests with a fully developed gap mosaic and the absence of traces of any anthropogenic influences in the soil, namely: fires, plowing, uprooting of trees, excavation of animal holes, etc., reveals their similarity.

The pore space in well-structured soils created by the digging invertebrates and vertebrates accounts for $50-70 \%$ of the total soil volume, which corresponds to the volume of open spaces (gaps) in the aboveground part of the forests.

The pore space in soils determines the air, water and temperature regimes that are optimal for soil inhabitants, and, consequently, the wealth of soil inhabitants, the optimal conditions for the functioning of plant root systems and the productivity of communities as a whole. A complex spatial environment in the underground part is created due to the digging activity of animals [56].

In the aboveground part, the combination of the closed forest areas and gaps in the stand creates the conditions for the coexistence of a huge variety of plant species, animals and representatives of other kingdoms within the same ecosystem by the maintenance of the maximal possible diversity of the Biota as a whole as the basis of its sustainability.

Destruction of the giant phytophagous mammoth complex almost completed by the middle of the Holocene was the first but very significant violation of the ecosystem functions of the Biota that led to significant losses of species diversity and soil fertility, weakening of the climate-regulating functions of the Biota.

It should be noted that the widespread grazing of livestock in Northern Eurasia forests somewhat decelerated the degradation of soil fertility due to the excreta in the soil. However, the massive spread of slash-and-burn agriculture led to huge losses in the soil fertility of the forest areas and the replacement of the natural living cover of the Northern Eurasia with the natural-anthropogenic cover. The whole territory of the European part of Russia where modern protected areas are located has been repeatedly cultivated by the slash-andburn agriculture [50]. Fires are catastrophic for the forest Biota: they lead to the burning of vegetation, 
bedding, humus and the death of the aboveground and underground animals. Besides, the fires disrupt the soil structure for the soil aggregation and porosity decrease as a result of the combustion of cementitious organic material. The litter burning exposes the mineral surfaces and leads to the leaching of mineral substances thus leading to the formation of nutrient-poor podzolic soils [57].

As a result, the living conditions of soil invertebrates have changed dramatically: the vital activity of soil saprophages, including the elements of mineral nutrition in the cycle, began to depend mainly on the quality of the litter of woody plants and the ground cover. At present, the most complete complex of saprophages has been preserved only in the forests with the coniferous and deciduous trees; the closed areas of the stand alternate with the renewal gaps that result from the death of large old trees and tall grasses, including large grasses that dominate the ground cover. The complex of soil formers is incomplete in the arrays of boreal forests dominated by the coniferous trees and the absence of tall grass in the ground cover [58, 59]. The soil block of saprophages is clearly depleted even in the best-preserved 300-400-year-old dark coniferous forests of the Pechora-Ilychsky reserve due to the absence of large mammalian phytophages; earthworms are represented by two groups in the forests (litter and soil-litter ones), which biomass is usually very low [60].

The experiments on the inclusion of large mammals, most often bison, in modern forests are being carried out in some protected areas. Such complex and expensive activities are carried out without evaluation of the soil condition (granulometric composition, humus capacity, main macroand microelement content, acidity) and soil biota population (representation of the main functional groups of the macro-, meso- and microfauna ensuring for the processing of the organic materials; fungi and bacteria as final litter destructors included into the fertilizer element cycle). The reintroduction measures are largely unreasonable without at least a general evaluation since the soil and soil biota condition affects the development of the bison food supply including a huge variety of grasses, bushes and trees being the most significant food resource. Thus, the analysis of the soil biota of the Orlovskoye Polesye National Park has demonstrated that the complex of coprophages and detritophages in the forests remains incomplete even 20 years after the bison introduction: only the litter and proper soil earthworms as the key soil formers live in the forest communities prevailing by area on sandy soils, and the bison excrements remain for long in the initial stages of decomposition on the soil surface in these forests and are not included into the fertilizer element cycle [61].

Such soils poor in animal populations remain as a result of previous economic activities: first of all, burning [62-64] and plowing [65-68]. Internationally the similar problems were faced before: manure was stored and accumulated in the pastures of Australia and North America due to the absence of coprophages. The problem was solved after the introduction of dung beetles [69-71].

Therefore, the results of the generalization of the constantly accumulating information on the nature in Northern Eurasia from the end of the Pleistocene to the Late Holocene can be formulated as follows:

1. The formation of the modern forest belt in Northern Eurasia dissected into the so-called "natural areas" is the result of the consistent occupation of the Biota by the only species on Earth that has achieved absolute domination - Homo Sapiens - in the process of the appropriating economy and, then, the producing economy.

2. Thus, the result of this domination led to a constantly increasing and fast spreading weakening of the climate regulating functions of the Biota which became one of the most significant, but yet underestimated factors for the preservation of LIFE on Earth. This determines the need for urgent measures for the restoration of the climate control and other Biota functions. At the same time, it is advisable to consider the areas that contact with the reserves as model polygons for the development of the systems of approaches and methods for reintroduction not of individual species, but of the full composition of the prehistoric Biota preserved in different refugia and their complexes.

\section{Practical recommendations}

The following studies should be performed for evaluating the capabilities of the modern reserves in the Northern Eurasian forest belt to maintain the highest possible biological diversity and structural and functional organization of ecosystems:

1) generalization of paleo data on the ranges of key species of plants and animals of the end of the Pleistocene-Middle Holocene period when most active extermination of large animals in the framework of the appropriating economy in the analyzed territory took place;

2) synthesis of the reintroduction experience of different representatives of the Biota of the analyzed territory within their natural range;

3) collection of historical and archival data on the times, methods and rates of the environmental management in the analyzed area; 
4) reconstruction of the potential composition of the aboveground and soil component of the Biota and comparison of Biota protected areas in similar environmental conditions based on the analysis of the literature and field observations of the state of BIOTA preserved in protected areas;

5) creation of a model reconstruction of the species composition and structural and functional organization of the Biota of the analyzed protected areas based on the existing paleo data and historical and archival information on the times, methods and rates of development of the analyzed territory. The already conducted studies in the geographically and ecologically similar conditions can be used as supplementary data;

6) identification of the most significant losses in the species composition of key species of animals, plants and representatives of other kingdoms, as well as the evaluation of the possibility of restoring their populations: presence of the necessary habitats and food resources;

7) arealogical and ecological analysis of most (all) inhabitants of the analyzed territories and evaluation of the possibility of their reintroduction using special programs and databases;

8) performance of a series of experiments on the reintroduction of species and their complexes destroyed in the process of nature management at biospheric sites as the main experimental sites of protected areas;

9) analysis of the possibility of using traditional methods of environmental management, such as moderate episodic grazing in livestock forests, simulating the effects of large herd phytophages completely exterminated by the time of the protected area organization;

10) performance of volunteer activities for the reconstruction of destroyed species and their groups in the aboveground and soil parts of the Biota based on regular classes organized by the Environmental Education Department employees with the protected area volunteers and schoolchildren.

The solution of the designated tasks undoubtedly requires a fundamental change in the state policy with respect to the protected areas, the last remaining "fragments" of pre-anthropogenic Biota.

The research was carried out within the framework of the State Task of the Center for Problems of Ecology and Productivity of Forests, Russian Academy of Sciences AAAA-A18-118052400130-7, with the financial support of the Russian Foundation for Basic Research (19-04-00-609 A).

\section{References}

1. Pleistocene rewilding: an optimistic agenda for twenty-first century conservation / J. C. Donlan, J. Berger, C. E. Bock, J. H. Bock, D. A. Burney, J. A. Estes, D. Foreman, P. S. Martin, G. W. Roemer, F. A. Smith, M. E. Soule, H. W. Greene // The American Naturalist. - Vol. 168 (5). - P. 660-681. - DOI 10.1086/508027.

2. Smirnova, O. V. Potential ecosystem cover - a new approach to the conservation biology / O. V. Smirnova, N. A. Toropova // Russian Journal of Ecosystem Ecology. - 2016. - Vol. 1 (1). - P. 1-20. - DOI 10.21685/25000578-2016-1-1

3. Биотическая регуляция окружающей среды / В. В. Горшков, В. Г. Горшков, В. И. Данилов-Данльян, К. С. Лосев, А. М. Макарьева // Экология. - 1999. - № 2. - С. 105-113.

4. Linking biodiversity to ecosystem function: implications for conservation biology / M. W. Schwartz, C. A. Brigham, J. D. Hoeksema, K. G. Lyons, M. H. Mills, P. J. van Mantgem // Oecologia. - 2000. - Vol. 122. P. 297-305.

5. Букварева, Е. Н. Ключевая экономическая ценность средообразующие функции живой природы и новая стратегия природопользования / Е. Н. Букварева // Методы решения экологических проблем. - Сумы : Издво СумГУ, 2010. - С. 100-124.

6. Ленькова, А. Оскальпированная земля / А. Ленькова. - Москва : Прогресс, 1971. - 276 с.

7. Реймерс, Н. Ф. Особо охраняемые природные территории / Н. Ф. Реймерс, Ф. Р. Штильмарк. - Москва : Мысль, 1978. - 151 с.

8. Соколов, В. Е. Экология заповедных территорий России / В. Е. Соколов ; под ред. В. Е. Соколова, В. Н. Тихомирова. - Москва : Янус-К, 1997. - 575 с.

9. Леви, К. Г. Радиоуглеродная хронология природных и социальных феноменов Северного полушария / К. Г. Леви, Н. В. Задонина, С. А. Язев. - Иркутск : Изд-во Иркутского гос. ун-та, 2009. - Т. 1. - 715 с.

10. Леви, К. Г. Радиоуглеродная хронология природных и социальных феноменов Северного полушария / К. Г. Леви, Н. В. Задонина, С. А. Язев. - Иркутск : Изд-во Иркутского гос. ун-та, 2011. - Т. 2. - 527 с.

11. Леви, К. Г. Радиоуглеродная хронология природных и социальных феноменов Северного полушария / К. Г. Леви, Н. В. Задонина, С. А. Язев. - Иркутск : Изд-во Иркутского гос. ун-та, 2011. - Т. 3. - 847 с.

12. Owen-Smith, N. Megafaunal extinctions: the conservation message from 11000 Years B.P. / N. Owen-Smith // Conserv. Biology. - 1989. - Vol. 3 (4). - P. 405-412.

13. Owen-Smith, N. Pleistocene extinctions: the pivotal role of megaherbivores / N. Owen-Smith // Paleobiology. 1987. - Vol. 13. - P. 351-162. 
14. Пучков, П. В. Некомпенсированные вюрмские вымирания. Сообщение 1. Крупнейшие растительноядные: эври- или стенобионты? / П. В. Пучков // Вестник зоологии. - 1991. - № 5. - С. 45-53.

15. Пучков, П. В. Некомпенсированные вюрмские вымирания. Сообщение 2. Преобразование среды гигантскими фитофагами / П. В. Пучков // Вестник зоологии. - 1992. - № 1. - С. 58-66.

16. Пучков, П. В. Некомпенсированные вюрмские вымирания. Сообщение 3. Перепромысел, «недопромысел» и другие факторы / П. В. Пучков // Вестник зоологии. - 1992. - № 4. - С. 73-80.

17. Кульпин, Э. С. Решающий опыт / Э. С. Кульпин, В. И. Пантин // Генезис кризисов природы и общества в России. - Москва : Московский лицей, 1993. - Вып. 1. - 102 с.

18. Антипина, Е. Е. Некоторые проблемы изучения истории взаимодействия хозяйственной деятельности человека с природными биоценозами / Е. Е. Антипина, С. П. Маслов // Эволюционная и историческая антропоэкология. - 1994. - С. 111-120.

19. Смирнова, О. В. Современная зональность Восточной Европы как результат преобразования позднеплейстоценового комплекса ключевых видов / О. В. Смирнова, В. Н. Калякин, С. А. Турубанова, М. В. Бобровский // Мамонт и его окружение: 200 лет его изучения. - Москва : Геос, 2001. - С. 200-208.

20. Реконструкция истории лесного пояса Восточной Европы и проблема поддержания биологического разнообразия / О. В. Смирнова, С. А. Турубанова, М. В. Бобровский, В. Н. Коротков, Л. Г. Ханина // Успехи современной биологии. - 2001. - Т. 121 (2). - С. 144-159.

21. Калякин, В. Н. О современном и прошлом распространении речного бобра в Сибири / В. Н. Калякин, С. А. Турубанова // Итоги и перспективы развития териологии Сибири : материалы науч. конф. (24-26 мая 2001 г.). - Иркутск : Иркут. гос. сельхоз. акад., 2001. - С. 99-103.

22. Турубанова, С. А. О распространении позднего мамонта в Сибири и индикационном значении этого вида / С. А. Турубанова, В. Н. Калякин // Итоги и перспективы развития териологии Сибири : материалы науч. конф. (24-26 мая 2001 г.). - Иркутск : Иркут. гос. сельхоз. акад., 2001. - С. 41-44.

23. Калякин, В. Н. Распространение мамонта в позднем плейстоцене и голоцене и трансформация природных экосистем / В. Н. Калякин, С. А. Турубанова // Материалы Московского центра РГО. Биогеография. Москва, 2002. - Вып. 10. - С. 34-40.

24. Турубанова, С. А. Экологический сценарий истории формирования живого покрова Европейской России и сопредельных территорий на основе реконструкции ареалов ключевых видов животных и растений : автореф. дис. ... канд. биол. наук / Турубанова С. А. - Москва, 2002. - 23 с.

25. Бобровский, М. В. Антропобиотическая концепция в применении к эволюции почв лесной зоны / M. В. Бобровский // Проблемы эволюции почв : материалы IV Всерос. конф. - Пущино : ОНТИ ПНЦ РАН, 2003. - C. 221-227.

26. Kalyakin, V. N. Some features of the transformation of mammal faunas of the palearctic and nearctic in the terminal cenozoic / V. N. Kalyakin // Russian Journal of Ecosystem Ecology. - 2016. - Vol. 1 (3). - DOI 10.21685/2500-0578-2016-3-1.

27. Харитоненков, М. А. Роль антропогенного фактора в формировании растительного покрова юга западносибирской равнины в эпоху традиционного природопользования (с позднего палеолита до конца ХІХ в.) : автореф. дис. ... канд. биол. наук / Харитоненков М. А. - Москва, 2012. - 25 с.

28. European Russian Forest. Their Current State and Features of Their History. Plant and Vegetation / ed. by O. V. Smirnova, M. V. Bobrovsky, L. G. Khanina. - Springer, 2017. - Vol. 15. - 476 p.

29. Оценка и сохранение биоразнообразия лесного покрова в заповедниках Европейской России / отв. ред. Л. Б. Заугольнова. - Москва : Научный мир, 2000. - 196 с.

30. Восточноевропейские леса: история в голоцене и современность / отв. ред. О. В. Смирнова. - Москва : Наука, 2004. - Кн. 1. - 479 с.

31. Verechagin, N. K. The ecological structure of the "Mammoth Fauna" in Eurasia / N. K. Verechagin, G. F. Baryshnikov // Ann. Zool. Fennici. - 1992. - Vol. 28. - P. 253-259.

32. Алексеева, Л. И. Териофауна верхнего плейстоцена Восточной Европы (крупные млекопитающие) / Л. И. Алексеева. - Москва : Наука, 1989. - 109 с.

33. Алексеева, Л. И. Конечная фаза развития позднеледниковой териофауны (по материалам центральных районов Русской равнины) / Л. И. Алексеева, С. В. Тихомиров // Материалы по мамонтовой фауне Северной Евразии. - 1989. - Т. 198. - С. 111-118. - (Тр. ЗИН АН СССР).

34. Верещагин, Н. К. Вымирание млекопитающих в четвертичном периоде Северной Евразии / Н. К. Верещагин, Г. Ф. Барышников // Тр. ЗИН АН СССР. - 1985. - Т. 131. - С. 3-38.

35. Верховская, Н. Б. Мамонтовые экосистемы и причины их исчезновения / Н. Б. Верховская // Журн. общ. биол. - 1988. - Т. 49 (1). - С. 70-83.

36. Алейников, А. А. Динамика растительного покрова долин малых рек в результате строительной деятельности бобров / А. А. Алейников // Вестник МГУЛ - Лесной вестник. - 2010. - № 3. - С. 165-168.

37. Батюшкова, И. В. История геологии / И. В. Батюшкова. - Москва : Наука, 1973. - 388 с.

38. Хэллем, Э. Великие геологические споры : пер. с англ. / Э. Хэллем. - Москва : Мир, 1985. - 216 с.

39. Имбри, Д. Тайны ледниковых эпох. Полтора века в поисках разгадки : пер. с англ. / Д. Имбри, К. П. Имбри. - Москва : Прогресс, 1988. - 263 с. 
40. Skufyin, P. K. Chuvardinsky's antiglacial (generalized geological) conception / P. K. Skufyin, Yu. N. Golubchikov, S. P. Evdokimov, A. A. Predovsky // Russian Journal of Ecosystem Ecology. - 2016. - Vol. 1 (4). DOI 10.21685/2500-0578-2016-4-1.

41. Крапивнер, Р. Б. Кризис ледниковой теории: аргументы и факты / Р. Б. Крапивнер. - Москва : Геос, 2018. $320 \mathrm{c}$.

42. Калякин, В. Н. Альтернатива гипотезе гигантских покровных оледенений / В. Н. Калякин // Биогеография. 2003. - Вып. 11. - С. 63.

43. Ломоносов, М. В. О слоях земных / М. В. Ломоносов. - Москва ; Ленинград, 1949. - 211 с.

44. Пидопличко, И. Г. О ледниковом периоде / И. Г. Пидопличко. - Вып. 4. - Киев : Изд-во АН УССР, 1956. $336 \mathrm{c.}$

45. Чувардинский, В. Г. О ледниковой теории и ее устоях (ответ рецензентам) / В. Г. Чувардинский // Геоморфология. - 2001. - № 1. - С. 103-106.

46. Чувардинский, В. Г. О ледниковой теории. Происхождение образований ледниковой формации / В. Г. Чувардинский. - Апатиты : КНЦ РАН, 1998. - 302 с.

47. The large mean body size of mammalian herbivores explains the productivity paradox during the Last Glacial Maximum / D. Zhu, P. Ciais, J. Chang, G. Krinner, S. Peng, N. Viovy, J. Pecuelas, S. Zimov // Nature Ecology \& Evolution. - 2018. - Vol. 2 (4). - P. 640.

48. Steppe-tundra transition: a herbivore-driven biome shif at the end of the Pleistocene / V. I. Chuprynin, A. P. Oreshko, F. S. Chapin III, J. F. Reynolds, M. C. Chapin // The American Naturalist. - 1995. - Vol. 146 (5). P. 765-794.

49. Zimov, S. A. Mammoth steppe: a high-productivity phenomenon / S. A. Zimov, N. S. Zimov, A. N. Tikhonov, F. S. Chapin III // Quaternary Science Reviews. - 2012. - Vol. 57. - P. 26-45.

50. Бобровский, М. В. Лесные почвы Европейской России: биотические и антропогенные факторы формирования / М. В. Бобровский. - Москва : KMK Publ, 2010. - 359 с.

51. Horton, T. R. The molecular revolution in ectomycorrhizal ecology: peeking into the black box / T. R. Horton, T. D. Bruns // Molecular ecology. - 2001. - Vol. 10 (8). - P. 1855-1871.

52. ДНК-штрихкодирование: сколько видов дождевых червей живет на юге Западной Сибири? / С. В. Шеховцов, Н. Э. Базарова, Д. И. Берман, Н. А. Булахова, Е. В. Голованова, С. В. Коняев, С. Е. Пельтек // Вавиловский журнал генетики и селекции. - 2016. - Т. 20 (1). - С. 125-130.

53. Edwards, C. A. Biology ofearthworms / C. A. Edwards, J. R. Lofty. - London : Chapman and Hall, 1972. - 283 p.

54. Докучаев, В. В. Русский чернозем: Отчет Имп. Вольн. экон. о-ва / В. В. Докучаев. - Санкт-Петербург, 1883 ; Москва : Сельхозиздат, 1952. - 460 с.

55. Begon, M. Ecology: Individuals, Populations and Communities / M. Begon, J. L. Harper, C. R. Townsend. - Oxford : Blackwell Scientific Publications, 1986. - 1068 p.

56. Ковда, В. А. Основы учения о почвах: Общая теория почвообразовательного процесса / В. А. Ковда. Москва : Наука, 1973. - С. 23-45.

57. Пономаренко, Э. В. Методические подходы к анализу суксессионных процессов в почвенном покрове / Э. В. Пономаренко // Суксессионные процессы в заповедниках России и проблемы сохранения биологического разнообразия. - Санкт-Петербург : Русское ботаническое общество, 1999. - С. 34-57.

58. Перель, Т. С. Распространение и закономерности распределения дождевых червей фауны СССР / Т. С. Перель. - Москва : Наука, 1979. - 272 с.

59. Стриганова, Б. Р. Питание почвенных сапрофагов / Б. Р. Стриганова. - Москва : Наука, 1980. - 244 с.

60. Гераськина, А. П. Население дождевых червей (Lumbricidae) в основных типах темнохвойных лесов Печоро-Илычского заповедника / А. П. Гераськина // Зоологический журнал. - 2016. - Т. 95 (4). - С. $394-405$.

61. Гераськина, А. П. Влияние реинтродукции зубров на комплексы дождевых червей национального парка «Орловское Полесье» / А. П. Гераськина, Л. Л. Киселева, А. П. Карпачев, М. Н. Абадонова // Russian Journal of Ecosystem Ecology. - 2018. - Vol. 3 (4). - DOI 10.21685/2500-0578-2018-4-4.

62. Безкоровайная, И. Н. Трансформация комплексов почвенных беспозвоночных при низовых пожарах разной интенсивности / И. Н. Безкоровайная, Е. Н. Краснощекова, Г. А. Иванова // Известия Российской академии наук. Серия биологическая. - 2007. - № 5. - С. 619-625.

63. Moretti, M. Biodiversity and resilience of arthropod communities after fire disturbance in temperate forests / M. Moretti, P. Duelli, M. K. Obrist // Oecologia. - 2006. - Vol. 149 (2). - P. 312-327.

64. Гонгальский, К. Б. Структурно-функциональная организация почвенной биоты после лесных пожаров : автореф. дис. ... докт. биол. наук / Гонгальский К. Б. - Москва, 2018. - 48 с.

65. Сигида, Р. С. Влияние возделываемых культур на комплексы жужелиц агроценозов Центрального Предкавказья / Р. С. Сигида // Молодежная аграрная наука: состояние, проблемы и перспективы развития : сб. науч. тр. - Ставрополь : Изд-во АГРУС, 2007. - С. 123-128.

66. Булгакова, М. А. Состав и численность дождевых червей как косвенный показатель физических свойств почв степных агроценозов Предуралья / М. А. Булгакова // Современные проблемы науки и образования. 2017. - № 2. - С. 227. 
67. Neave, P. Response of soil invertebrates to reduced tillage systems established on a clay loam soil / P. Neave, C. A. Fox // Applied Soil Ecology. - 1998. - Vol. 9 (1-3). - P. 423-428.

68. Pelosi, C. Searching for a more sensitive earthworm species to be used in pesticide homologation tests-a metaanalysis / C. Pelosi, S. Joimel, D. Makowski // Chemosphere. - 2013. - Vol. 90 (3). - P. 895-900.

69. Barley, K. P. The abundance of earthworms in agricultural land and their possible significance in agriculture / K. P. Barley // Advances in Agronomy. - 1961. - Vol. 13. - P. 249-268.

70. Bornemissza, G. F. Australian dung beetle project 1965-75 / G. F. Bornemissza // Australian Meat Research Committee. - 1976. - Vol. 30. - P. 1-30.

71. Kohlmann, B. Dung Beetles in Subtmpical North America / B. Kohlmann ; ed. by I. Hanski, I. Cambefort // Dung Beetle Ecology. - New Jersey : Princeton University Press, 1991. - P. 116-132.

\section{References}

1. Donlan J. C., Berger J., Bock C. E., Bock J. H., Burney D. A., Estes J. A., Foreman D., Martin P. S., Roemer G. W., Smith F. A., Soule M. E., Greene H. W. The American Naturalist. Vol. 168 (5), pp. 660-681. DOI $10.1086 / 508027$.

2. Smirnova O. V., Toropova N. A. Russian Journal of Ecosystem Ecology. 2016, vol. 1 (1), pp. 1-20. DOI 10.21685/2500-0578-2016-1-1.

3. Gorshkov V. V., Gorshkov V. G., Danilov-Danl'yan V. I., Losev K. S., Makar'eva A. M. Ekologiya [Ecology]. 1999 , no. 2, pp. 105-113.

4. Schwartz M. W., Brigham C. A., Hoeksema J. D., Lyons K. G., Mills M. H., van Mantgem P. J. Oecologia. 2000, vol. 122, pp. 297-305.

5. Bukvareva E. N. Metody resheniya ekologicheskih problem [Methods for solving environmental problems]. Sumy: Izd-vo SumGU, 2010, pp. 100-124.

6. Len'kova A. Oskal'pirovannaya zemlya [Scalped Earth]. Moscow: Progress, 1971, 276 p.

7. Rejmers N. F., Shtil'mark F. R. Osobo ohranyaemye prirodnye territorii [Protected areas]. Moscow: Mysl', $1978,151 \mathrm{p}$.

8. Sokolov V. E. Ekologiya zapovednyh territorij Rossii [Ecology of Russian conservation areas]. Moscow: Yanus$\mathrm{K}, 1997,575 \mathrm{p}$

9. Levi K. G., Zadonina N. V., Yazev S. A. Radiouglerodnaya hronologiya prirodnyh i social'nyh fenomenov Severnogo polushariya [Radiocarbon chronology of natural and social phenomena in the Northern Hemisphere]. Irkutsk: Izd-vo Irkutskogo gos. un-ta, 2009, vol. 1, 715 p.

10. Levi K. G., Zadonina N. V., Yazev S. A. Radiouglerodnaya hronologiya prirodnyh i social'nyh fenomenov Severnogo polushariya [Radiocarbon chronology of natural and social phenomena in the Northern Hemisphere]. Irkutsk: Izd-vo Irkutskogo gos. un-ta, 2011, vol. 2, 527 p.

11. Levi K. G., Zadonina N. V., Yazev S. A. Radiouglerodnaya hronologiya prirodnyh i social'nyh fenomenov Severnogo polushariya [Radiocarbon chronology of natural and social phenomena in the Northern Hemisphere]. Irkutsk: Izd-vo Irkutskogo gos. un-ta, 2011, vol. 3, 847 p.

12. Owen-Smith N. Conserv. Biology. 1989, vol. 3 (4), pp. 405-412.

13. Owen-Smith N. Paleobiology. 1987, vol. 13, pp. 351-162.

14. Puchkov P. V. Vestnik zoologii [Bulletin of Zoology]. 1991, no. 5, pp. 45-53.

15. Puchkov P. V. Vestnik zoologii [Bulletin of Zoology]. 1992, no. 1, pp. 58-66.

16. Puchkov P. V. Vestnik zoologii [Bulletin of Zoology]. 1992, no. 4, pp. 73-80.

17. Kul'pin E. S., Pantin V. I. Genezis krizisov prirody $i$ obshchestva v Rossii [Genesis of crises of nature and society in Russia]. Moscow: Moskovskij licej, 1993, iss. 1, 102 p.

18. Antipina E. E., Maslov S. P. Evolyucionnaya i istoricheskaya antropoekologiya [Evolutionary and historical anthropoecology]. 1994, pp. 111-120.

19. Smirnova O. V., Kalyakin V. N., Turubanova S. A., Bobrovskij M. V. Mamont i ego okruzhenie: 200 let ego izucheniya [Mammoth and its surroundings: 200 years of study]. Moscow: Geos, 2001, pp. 200-208.

20. Smirnova O. V., Turubanova S. A., Bobrovskij M. V., Korotkov V. N., Hanina L. G. Uspekhi sovremennoj biologii [Advances of modern biology]. 2001, vol. 121 (2), pp. 144-159.

21. Kalyakin V. N., Turubanova S. A. Itogi i perspektivy razvitiya teriologii Sibiri: materialy nauch. konf. (24-26 maya 2001 g.) [Results and prospects for the development of theriology in Siberia: proceedings of research conference (May 24-26, 2001)]. Irkutsk: Irkut. gos. sel'hoz. akad., 2001, pp. 99-103.

22. Turubanova S. A., Kalyakin V. N. Itogi i perspektivy razvitiya teriologii Sibiri: materialy nauch. konf. (24-26 maya 2001 g.) [Results and prospects for the development of theriology in Siberia: proceedings of research conference (May 24-26, 2001)]. Irkutsk: Irkut. gos. sel'hoz. akad., 2001, pp. 41-44.

23. Kalyakin V. N., Turubanova S. A. Materialy Moskovskogo centra RGO. Biogeografiya [Proceedings of the Moscow Center of the Russian Geographical Society. Biogeography]. Moscow, 2002, iss. 10, pp. 34-40.

24. Turubanova S. A. Ekologicheskij scenarij istorii formirovaniya zhivogo pokrova Evropejskoj Rossii i sopredel'nyh territorij na osnove rekonstrukcii arealov klyuchevyh vidov zhivotnyh $i$ rastenij: avtoref. dis. kand. biol. nauk [Ecological scenario of the history of living cover formation in European Russia and adjacent territories based on 
the reconstruction of ranges of key animal and plant species: abstract of thesis of the Candidate of Biological Sciences]. Moscow, 2002, 23 p.

25. Bobrovskij M. V. Problemy evolyucii pochv: materialy IV Vseros. konf. [Problems of soil evolution: materials of the $4^{\text {th }}$ All-Russian conference]. Pushchino: ONTI PNC RAN, 2003, pp. 221-227.

26. Kalyakin V. N. Russian Journal of Ecosystem Ecology. 2016, vol. 1 (3). DOI 10.21685/2500-0578-2016-3-1.

27. Haritonenkov M. A. Rol' antropogennogo faktora v formirovanii rastitel'nogo pokrova yuga zapadnosibirskoj ravniny $v$ epohu tradicionnogo prirodopol'zovaniya (s pozdnego paleolita do konca HIH v.): avtoref. dis. kand. biol. nauk [Role of anthropogenic factor in vegetation cover formation in the south of the West Siberian Plain under traditional nature management (from the late Paleolithic to the end of the 19th century): abstract of thesis of the Candidate of Biological Sciences]. Moscow, 2012, 25 p.

28. European Russian Forest. Their Current State and Features of Their History. Plant and Vegetation. Ed. by O. V. Smirnova, M. V. Bobrovsky, L. G. Khanina. Springer, 2017, vol. 15, 476 p.

29. Ocenka i sohranenie bioraznoobraziya lesnogo pokrova v zapovednikah Evropejskoj Rossii [Assessment and conservation of biodiversity of forest cover in the reserves of European Russia]. Execut. ed. L. B. Zaugol'nova. Moscow: Nauchnyj mir, 2000, 196 p.

30. Vostochnoevropejskie lesa: istoriya v golocene i sovremennost' [Eastern European forests: history in the Holocene and modernity]. Execut. ed. O. V. Smirnova. Moscow: Nauka, 2004, bk. 1, 479 p.

31. Verechagin N. K., Baryshnikov G. F. Ann. Zool. Fennici. 1992, vol. 28, pp. 253-259.

32. Alekseeva L. I. Teriofauna verhnego plejstocena Vostochnoj Evropy (krupnye mlekopitayushchie) [Teriofauna of the Upper Pleistocene in Eastern Europe (large mammals)]. Moscow: Nauka, 1989, 109 p.

33. Alekseeva L. I., Tihomirov S. V. Materialy po mamontovoj faune Severnoj Evrazii [Materials on mammoth fauna in Northern Eurasia]. 1989, vol. 198, pp. 111-118. (Tr. ZIN AN SSSR).

34. Vereshchagin N. K., Baryshnikov G. F. Tr. ZIN AN SSSR [Proceedings of the Zoological Institute of the USSR Academy of Sciences]. 1985, vol. 131, pp. 3-38.

35. Verhovskaya N. B. Zhurn. obshch. biol. [Journal of general biology]. 1988, vol. 49 (1), pp. 70-83.

36. Alejnikov A. A. Vestnik MGUL - Lesnoj vestnik [Bulletin of MGUL - Forest Bulletin]. 2010, no. 3, pp. $165-168$.

37. Batyushkova I. V. Istoriya geologii [History of geology]. Moscow: Nauka, 1973, 388 p.

38. Hellem E. Velikie geologicheskie spory: per. s angl. [Great geological disputes: translated from English]. Moscow: Mir, 1985, $216 \mathrm{p}$.

39. Imbri D., Imbri K. P. Tajny lednikovyh epoh. Poltora veka v poiskah razgadki: per. s angl. [Mystery of the Ice Ages. Century and a half in search for a solution: translated from English]. Moscow: Progress, 1988, 263 p.

40. Skufyin P. K., Golubchikov Yu. N., Evdokimov S. P., Predovsky A. A. Russian Journal of Ecosystem Ecology. 2016, vol. 1 (4). DOI 10.21685/2500-0578-2016-4-1.

41. Krapivner R. B. Krizis lednikovoj teorii: argumenty $i$ fakty [Crisis of the glacial theory: arguments and facts]. Moscow: Geos, 2018, 320 p.

42. Kalyakin V. N. Biogeografiya [Biogeography]. 2003, iss. 11, p. 63.

43. Lomonosov M. V. O sloyah zemnyh [On the earth layers]. Moscow; Leningrad, 1949, 211 p.

44. Pidoplichko I. G. O lednikovom periode [On the glacial period]. Issue. 4. Kiev: Izd-vo AN USSR, 1956,336 p.

45. Chuvardinskij V. G. Geomorfologiya [Geomorphology]. 2001, no. 1, pp. 103-106.

46. Chuvardinskij V. G. O lednikovoj teorii. Proiskhozhdenie obrazovanij lednikovoj formacii [On the glacial theory. Origin of building-ups in the glacial formation]. Apatity: KNC RAN, 1998, $302 \mathrm{p}$.

47. Zhu D., Ciais P., Chang J., Krinner G., Peng S., Viovy N., Pesuelas J., Zimov S. Nature Ecology \& Evolution. 2018, vol. 2 (4), p. 640.

48. Chuprynin V. I., Oreshko A. P., Chapin III F. S., Reynolds J. F., Chapin M. C. The American Naturalist. 1995, vol. 146 (5), pp. 765-794.

49. Zimov S. A., Zimov N. S., Tikhonov A. N., Chapin III F. S. Quaternary Science Reviews. 2012, vol. 57, pp. 2645.

50. Bobrovskij M. V. Lesnye pochvy Evropejskoj Rossii: bioticheskie $i$ antropogennye faktory formirovaniya [Forest soils in European Russia: biotic and anthropogenic factors of formation]. Moscow: KMK Publ, 2010, 359 p.

51. Horton T. R., Bruns T. D. Molecular ecology. 2001, vol. 10 (8), pp. 1855-1871.

52. Shekhovcov S. V., Bazarova N. E., Berman D. I., Bulahova N. A., Golovanova E. V., Konyaev S. V., Pel'tek S. E. Vavilovskij zhurnal genetiki i selekcii [Vavilov journal of genetics and selection]. 2016, vol. 20 (1), pp. 125-130.

53. Edwards C. A., Lofty J. R. Biology of earth worms. London: Chapman and Hall, 1972, 283 p.

54. Dokuchaev V. V. Russkij chernozem: Otchet Imp. Vol'n. ekon. o-va [Russian black soil: Report of the Empire Free Economic Society]. Saint-Petersburg, 1883; Moscow: Sel'hozizdat, 1952, 460 p.

55. Begon M., Harper J. L., Townsend C. R. Ecology: Individuals, Populations and Communities. Oxford: Blackwell Scientific Publications, 1986, 1068 p.

56. Kovda V. A. Osnovy ucheniya o pochvah: Obshchaya teoriya pochvoobrazovatel'nogo processa [Fundamentals of soils theory: General theory of soil-forming process]. Moscow: Nauka, 1973, pp. 23-45.

57. Ponomarenko E. V. Sukcessionnye processy v zapovednikah Rossii i problemy sohraneniya biologicheskogo raznoobraziya [Succession processes in Russian reserves and problems of preserving biological diversity]. SaintPetersburg: Russkoe botanicheskoe obshchestvo, 1999, pp. 34-57.

58. Perel' T. S. Rasprostranenie i zakonomernosti raspredeleniya dozhdevyh chervej fauny SSSR [Distribution and distribution patterns of earthworms of the USSR fauna]. Moscow: Nauka, 1979, 272 p. 
59. Striganova B. R. Pitanie pochvennyh saprofagov [Nutrition of soil saprophages]. Moscow: Nauka, 1980,244 p.

60. Geras'kina A. P. Zoologicheskij zhurnal [Zoological journal]. 2016, vol. 95 (4), pp. 394-405.

61. Geras'kina A. P., Kiseleva L. L., Karpachev A. P., Abadonova M. N. Russian Journal of Ecosystem Ecology. 2018, vol. 3 (4). DOI 10.21685/2500-0578-2018-4-4.

62. Bezkorovajnaya I. N., Krasnoshchekova E. N., Ivanova G. A. Izvestiya Rossijskoj akademii nauk. Seriya biologicheskaya [Bulletin of the Russian Academy of Sciences. Biological series]. 2007, no. 5, pp. 619-625.

63. Moretti M., Duelli P., Obrist M. K. Oecologia. 2006, vol. 149 (2), pp. 312-327.

64. Gongal'skij K. B. Strukturno-funkcional'naya organizaciya pochvennoj bioty posle lesnyh pozharov: avtoref. dis. dokt. biol. nauk [Structural and functional organization of soil biota after forest fires: abstract of thesis of the Doctor of Biological Sciences]. Moscow, 2018, 48 p.

65. Sigida R. S. Molodezhnaya agrarnaya nauka: sostoyanie, problemy i perspektivy razvitiya: sb. nauch. tr. [Youth agrarian science: state, problems and prospects for development: proceedings]. Stavropol: Izd-vo AGRUS, 2007, pp. $123-128$.

66. Bulgakova M. A. Sovremennye problemy nauki $i$ obrazovaniya [Modern problems of science and education]. 2017, no. 2, p. 227.

67. Neave P., Fox C. A. Applied Soil Ecology. 1998, vol. 9 (1-3), pp. 423-428.

68. Pelosi C., Joimel S., Makowski D. Chemosphere. 2013, vol. 90 (3), pp. 895-900.

69. Barley K. P. Advances in Agronomy. 1961, vol. 13, pp. 249-268.

70. Bornemissza G. F. Australian Meat Research Committee. 1976, vol. 30, pp. 1-30.

71. Kohlmann B. Dung Beetle Ecology. New Jersey: Princeton University Press, 1991, pp. 116-132. 